\title{
ESO objects to police 'harassment' in course of telescope dispute
}

London. A sharp dispute over the construction of the world's largest optical telescope on a mountain top in northern Chile entered a new phase last week when Chilean police forced their way into the local offices of the European Southern Observatory (ESO).

Javier Jimenez, a Chilean judge, accompanied by a contingent of local police, entered the ESO buildings in the town of Cerro Paranal, at the base of the mountain that includes the observatory site, at lunchtime on 30 March.

After what is described as a "tense" but incident-free 90 minute visit, the officials left the offices armed with photographs and a comprehensive inventory of all building work completed since a court ordered the initial suspension of telescope construction last spring (see Nature 378, 676; 1994).

ESO officials were told by Jimenez as he left that any work completed after the ban would be demolished, and that ESO's

Work in progress: construction of the Very Large Telescope on Mount Paranal remains the subject of controversy over land ownership. eight member states would have to cover the costs. "This situation is totally unprecedented," says Richard M. West, a spokesman for ESO, which is based in Munich, Germany. "In our opinion, this is a clear violation of international law."

In a statement, ESO said that the act of the Chilean court had raised "to a new level the quality of the harassment to its activities in Chile" and would result in "substantial financial damage" to the Very Large Telescope (VLT) project.

The Chilean courts last year ordered construction work on the DM500-million (US\$360 million) (VLT) to stop when a Chilean family, the Latorres, filed an appli-

cation claiming ancestral ownership of the VLT's proposed site, donated to ESO by Chile in 1987.

ESO opposed the suspension on the grounds that an intergovernmental agency should be immune from local laws and that the dispute over land ownership was between the Latorres and the Chilean government, rather than with ESO, which has agreeed with the government to construct

IMAGE
UNAVAILABLE
FOR COPYRIGHT
REASONS

the telescope by 1997. "We never agreed with the injunction to stop work," says West. "We are the unfortunate third party."

While the Latorres family has been pursuing its case in the courts - it is now before Chile's higher supreme court - ESO has stuck to its original construction timetable, in the belief that the Chilean government, under the terms of the agreement, will eventually grant immunity from any court decision going against the observatory.

Last week's police action, however, marks a turning point in the dispute, and could have wider implications. Some feel that it has laid Chile open to suggestions that the state has shown itself unable to honour

\section{Takeda gains access to HGS data-bank}

London. Takeda Chemical Industries Ltd., Japan's largest pharmaceutical company, last week signed an agreement with Britain's SmithKline Beecham (SB) giving it access to sequence data on the human genome which the British company has licensed under a $\$ 120$ million deal with Human Genome Sciences (HGS) Inc. of Rockville, Maryland.

According to Kunion Takeda, the president of the Japanese company which has recently been seeking to expand its efforts in basic research, the collaboration with SB and the access to HGS's gene sequence data base will allow it to "efficiently utilize genomic information for drug discovery."
Other companies are reported to have been reluctant to enter agreements with SB to use the HGS data because of the terms under which access is being offered (see Nature, 371, 463; 1994). But a statement from SmithKline says that, under the terms of a letter of intent signed with Takeda, the two companies will collaborate on research in "the discovery and development of novel pharmaceuticals based on genomic technology."

In addition to gaining access to sequencing data produced by HGS and The Institute for Genomic Research, the agreement will also allow the Japanese company to make use of bioinformatics technology developed by SB and HGS. intergovernmental accords - and suggest that this could damage the country's attempts to lure much-needed foreign investment. "This is a very serious matter," says West. "It means that an agreement with Chile is no guarantee that your property will be protected."

An extraordinary meeting of ESO's governing council has been called to discuss the Chilean situation. West says that when they meet, the council's 16 members - made up of one politician and one astronomer from each member state - will be prepared to discuss "all available options".

These are widely thought to include the possibility of moving the observatory site out of Chile - and perhaps even abandoning the project altogether. The latter option, however, is not generally thought to be realistic, as 70 per cent of the project's budget has already been committed. The telescopes are already in production, while the buildings are practically ready for use.

Meanwhile, Chile's own astronomers have mixed feelings about the telescope, disappointed that they have not been allocated more time on the facility when it is eventually completed. Monica Rubio, an astronomer at the University of Chile, complains that the land dispute has overshadowed the issue of time for Chilean astronomers, which is far more crucial for Chilean science.

Rubio and other astronomers say the allocation of 10 per cent of the telescope's operational time for Chilean astronomers has still not been guaranteed by the government. "We are not asking for anything special," she says. "In Hawaii [the site of several US and European telescopes], the quota is 15 per cent, while it is 20 per cent [for Spanish astronomers] in the Canary Islands."

Rubio says that if Chilean astronomers do not get the guarantee they are seeking, "the telescope might as well be in a different country; it will make no difference to Chile". Others claims that Chilean public opinion is remains mixed about the whole dispute, with many people arguing that the Latorres should be compensated if the land did indeed legally belong to them.

According to Rubio the difficulty for Chileans - as indeed it is for ESO - is that the issue is no longer about science. "It has, instead, become a symbol of the struggle between the political powers and the judiciary over decision-making in Chile," she says.

Ehsan Masood 